\title{
Physical fitness and sports medicine research in industrial/occupational health following public announcement of the new Total Health Promotion Plan guidelines
}

\author{
Yasumasa Eguchi $^{1^{*}}$ and Koji Mori ${ }^{2}$ \\ 1産業医科大学産業保健学部， ₹807-8555 北九州市八幡西区医生ヶ丘1-1 (School of Health Sciences, University of Occupa- \\ tional and Environmental Health, 1-1 Iseigaoka, Yahatanishi-ku, Kitakyushu 807-8555, Japan) \\ 2 産業医科大学産業生態科学研究所， ～807-8555 北九州市八幡西区医生ヶ丘1-1 (Institute of Industrial Ecological Sciences, \\ University of Occupational and Environmental Health, 1-1 Iseigaoka, Yahatanishi-ku, Kitakyushu 807-8555, Japan)
}

Received: July 30, 2020 / Accepted: August 7, 2020

\begin{abstract}
In present-day society with its proliferation of various work styles, many companies and workplaces are faced with the important and complicated tasks of maintaining and promoting workers' health. Amid this climate, the Ministry of Health, Labour and Welfare of Japan on March 31, 2020, announced its revised "Guidelines for Total Health Promotion Plan for Workers in Workplaces." This is a major revision of the original Total Health Promotion Plan (THP) that had been implemented up to that point. In the field of industrial/occupational health, physical activity and exercise are key topics addressed within the THP. This necessitates further study of physical fitness and sports medicine. In this study, based on societal trends and previous studies, we have reviewed the role of physical fitness and sports medicine research within the field of industrial/occupational health. We conclude it is important to clarify issues and objectives in each workplace and ways of concretizing plans to resolve and achieve them. Specific methods for doing so are diverse and indefinite, and creativity is required. Numerous options and types of tools should be created for applying outcomes on physical activity and exercise in accordance with the THP. Not only the viewpoint of avoiding risk, but also the viewpoints of accruing assets and taking a behavioral science approach toward continuing physical activity and exercise need to be considered. Research on these matters has not progressed sufficiently and we must advance a high volume of studies through various academic societies.
\end{abstract}

Jpn J Phys Fitness Sports Med, 69(6): 421-427 (2020)

Keywords : occupational health, industrial health, workplace, health promotion, THP

\section{はじめに}

近年, ICT (Information and Communication Technology）を中心とした急速な技術革新とともに, テレワー ク（telework)/リモートワーク（remote work）が拡大 していく社会情勢変化の下，労働者の働き方や就業意識 が大きく変化してきている，また，年代別の人口構成比 が変化する中，働けるうちは働き続けたいと願う人々は 非常に多く ${ }^{1)}$, 高齢労働者の比率は徐々に増加してきて いる，多様な働き方が広がっていく社会において，労働 者の健康保持増進を図っていくことは，企業，事業場等

*Correspondence: y-eguchi@med.uoeh-u.ac.jp
において重要かつ複雑な課題となっている。一方，従業 員等の健康管理を経営的な視点で考元, 戦略的に実践す る「健康経営」2) という理念が急速に広がってきている. 労働者が職場でいきいきと働けることで生産性が向上す れば，企業の経営が安定化し，結果的に労働者の賃金が 上昇して豊かな人生へのさらなる投資ができるようにな る, という好循環が期待されている。 このような状況下, 本年（令和 2 年） 3 月 31 日に, 改正「事業場に打ける労 働者の健康保持増進のための指針」(指針公示第 7 号) が公示され，4月1日から適用された ${ }^{3)}$ 。これまで「働 く人の心とからだの健康づくり」として推進されてきた THP (Total Health promotion Plan) の大幅な見直しで ある(以下, 新 THP 指針). 
身体活動・運動の推進は，上記のいずれの場面におい ても重要な位置づけとなっており, 日本体力医学会とし ても, 労衝衛生 - 産業保健分野に打ける今後の体力科学 研究のあり方に対するさらなる検討が必要となってきて いる，なぜなら，我が国の将来の発展に向けて，人口の 最も多くを占める世代である労働者の「元気さ」は非常 に重要だからである。そこで本研究では，労衝衛生・産 業保健分野に扔ける今後の体力科学研究のあり方につい て, 社会の趨勢や先行研究をもとに総説することを目的 とした.

\section{「新THP指針」と体力科学}

「新THP指針」の主なポイントは以下の通りである（文 献 3 をもとに作成).

(1)「ポピュレーションアプローチ」の視点の強化

旧指針では，生活習慣上の課題を有する労働者を主な 対象として, 運動指導や保健指導等を実施することが中 心の内容となっていたが, 新指針では幅広い労働者の健 康保持増進が促進されるように, 直ちに生活習慣上の課 題が見当たらない労働者も対象に含まれ，個人だけでな く一定の集団に対して活動を推進できるように「ポピュ レーションアプローチ」の視点が強化されている.

(2)労働者の積極的な参加を促すための取組の重視

健康保持増進に対する無関心層にも抵抗なく取り組ん でもらえるように, 労働者が無意識のうちに行動変容す るような環境づくりや，スポーツ等を楽しみながら参加 できる仕組みづくり等が重視されている。また，労働者 が健康保持増進に取り組む文化や風土を事業者が醸成し ていくことも推奨されている.

(3)労働者の高齢化を見据えた取組の重視

労働者が高年齢期を迎えても就業を継続できるよう， 若年期から加齢に伴う筋量の低下等による健康状態の悪 化を防ぐための運動習慣化等の視点を盛り込むことが推 奨されている.

以上の基本的な考え方に加え，これらを計画的に実践 していく上での重要なポイントとして以下の点が強調さ れている.

(4)健康保持増進対策を継続的かつ計画的に行う PDCAサ イクルの明確化

労働者等の意見を聴きつつ事業場の実態に即した取組 を中長期的視点に立って継続的かつ計画的に行うため, 衛生委員会等を活用して以下の項目に取り組むととも に, 各項目の内容について関係者に周知することが必要 と明記されている。

1) 健康保持増進方針の表明

2) 推進体制の確立

3 ）課題の把握

4 ）健康保持増進目標の設定
5 ）健康保持増進措置の決定

6 ) 健康保持増進計画の作成

7 ) 健康保持増進計画の実施

8 ）実施結果の評価

旧指針では，健康測定の一環として必要に応じて運動 機能検査（いわゆる体力測定）を行い，健康指導として の運動プログラムや実践援助へつなげるというのが $1 つ$ の特徵的なパターンであった。しかし，新指針では運動 機能検査が削除され，健康測定も必須ではなくなった。 これにより，これまでのようなパターン化された流れで はなく，それぞれの企業や事業所において，その職場の 実態に即した課題を抽出することで柔軟な対応が可能と なった。これからのTHPの推進においては，それぞれの 職場に扔ける課題や目標を明確化することがまず求めら れる。 その課題や目標をどのようにして解決, 達成して いくのかが重要となる。パターン化された流れでないた め裁量性は高くなるものの，それは反面でそれぞれの企 業・事業所の本当の実力が問われてくることとなる.

\section{労働衛生・産業保健分野における 現代の課題と体力科学}

労働衛生・産業保健分野において, 近年どのような課 題や方向性が存在するのか，身体活動・運動に関わる主 な内容について,「リスク回避要素」と「アセット形成要 素」の $2 つ に$ 分けて以下にまとめた4)。この 2 つの要素 は, Nutbeamが紹介しているへルスリテラシーのシンプ ルなモデルに基づく，それは「リスクファクター（risk factor) モデル」と,「アセット (asset) モデル」である ${ }^{5)}$. 「リスクファクターモデル」は，主に臨床的な考え方を 反映して扮り，不十分なへルスリテラシーが疾病の進行 や治療の障害等につながるという視点である。一方「ア セットモデル」は，主に公衆衛生分野の考え方を反映し て扔り，高いヘルスリテラシーはその人にとって資産 （アセット）であり，それにより健康的な行動をとった り，健康によい環境をつくるための社会活動に参加した りすることでより豊かな生活を送れるようになるという 視点である. Nutbeam は, どちらのモデルも重要であり, それぞれに関する研究が進められるべきであると提案し ている.

リスク回避要素と身体活動・運動 労働者における定期 健康診断での有所見率は 2017 年には $54.1 \%$ と半数を超 えており，特に脳・心臟疾患につながる血中脂質，血圧 等に係る有所見率が増加傾向にある ${ }^{6)}$ ，これらの予防・ 改善は職場に打ける重要な健康課題の1つである。労働 者に限らず，身体活動・運動の効果として，まずこの ような疾病リスクの回避を想定するのは当然と言える. ACSM (American College of Sports Medicine :アメリ 
カスポーツ医学会）が約 5 年ごとに更新している「運動 処方ガイドライン」の最新第 10 版では, 「身体活動·運動」 の主な健康関連効果 (エビデンスのあるもの) として,「死 亡率の低下（全死因）」はもとより，日本人の死因上位 である「がん」「心疾患」「脳血管疾患」の予防に直接的, 間接的に効果があることが示されている7 康日本21（第二次）でも強調されてきたものと同様で あり ${ }^{8)}$, 我が国に打ける健康づくり施策の基本となって いると言える。このうち「がん」のリスク軽減効果を部 位・種類別にみると, 強いエビデンスのあるものだけで, 結腸 (colon), 乳 (breast), 腎臓 (kidney), 子宮内膜 (endometrial), 膀胱 (bladder), 食道 (esophageal), 胃（stomach）などが，ACSMの最新の知見としてまと められている ${ }^{9)}$. がん患者の就労支援という視点からは, がんサバイバーの人々における倦点感（cancer related fatigue), 不安 (anxiety), 抑うつ (depression), リン パ浮腫 (lymphedema) といった，がんに伴う諸症状へ の緩和効果も強いエビデンスが示されている10). 一方で, 一般の人々より疲労が起こりやすいことが想像できるた め, どれくらいの強度でどれくらいの量を上限目安とす べきか，などに関する今後の研究成果が待たれるところ である

次に，労働現場に打ける大きなリスクの1つに「転倒 災害」がある。高齢労働者が増加するにしたがって職場 の転倒災害は高止まりしており, 労働災害死傷者の原 因第 1 位を 10 年以上続けている ${ }^{11)}$. 新THP指針におい ても，労働者の高齢化を見据えた取組が重視されてお り, 転倒リスクへの対応は職場に扮ける重要課題となる。 この転倒の予防と転倒による傷害の予防効果について も，身体活動・運動によるエビデンスのある効果として ACSM は示している7). 一方で, Gillespieらによるシス テマティックレビューでは ${ }^{12)}$ ，高齢者を対象としたもの ではあるものの，転倒予防に対する運動介入効果は，太 極拳や複合的な運動では認められる反面, 筋卜レ単独や ウォーキング単独では明らかな効果は示されていない. 労働者に㧍ける転倒予防効果については未だ十分なエビ デンスが確立しているとは言えず，今後の研究の進展が 求められる.

続いて, 職場の労働生産性低下というリスクに着目す ると，「アブセンティーイズム（absenteeism：疾病等に 起因する休業)」による経済的損失よりも, 出勤してい るものの労働遂行能力が低下している状態にある「プレ ゼンティーイズム (presenteeism)」による損失の方が 大きいことが明らかになっている ${ }^{13,14)}$. 労働遂行能力を 考慮したプレゼンティーイズムによる損失理由の上位に は「首の不調や肩こり」「腰痛」や「メンタルヘルス不調」 などが占めている，器質的疾患がある場合に治療を行う ことはもちろんであるが，身体活動・運動を継続的に行
うことにより軽快することも十分に期待できる症状群で あり，これらのリスクを回避することは重要である。身 体活動・運動には「首の不調や肩こり」「腰痛」に関連 する骨格筋系機能の健康度維持に加えストレス症状や抑 うつの改善効果があることも ACSM は示している7 ${ }^{7}$.

アセット形成要素と身体活動・運動 アセット形成要素 は,リスク回避要素と比べて緊急性は低いかもしれない が，労働者が生き生きと元気に働き続けるための要素と して重要である，企業などの組織に属して仕事をしてい く場合，他者とのコミュニケーションは重要である，身 体活動・運動をグループで実施することはコミュニケー ション機会の向上につながることは言うまでもない。ま た，良好な人間関係の形成や仕事でのチームワークの醇寒 成などもグループで身体活動・運動を実施することによ る効果が期待できる，身体活動・運動を一人で実施する よりもグループで実施するほうが健康状態の良い人が多 いという研究報告もあることから ${ }^{15)}$ ，身体活動・運動に よるコミュニケーション機会の向上がアセット形成に何 らかの効果を及ぼす可能性は高い。さらに，身体活動・ 運動の実施による活力・士気向上への効果なども, 企業 等の健康経営へのプラス効果が期待される。これらは職 場における重要なアセット形成と言え，健康経営の視点 からは特に重要と思われる。

次に,「はじめに」でも触れたように，高齢になっても 働き続けたいと願う人々は非常に多く, 現在仕事をして いる 60 歳以上の人の 8 割近くが, 少なくとも 70 歳くら いまでは働きたいと望んで㧍り，4割以上の人が㗢ける うちはいつまでも働きたいと願っていることが明らかに なっている1)。このことは，単に健康寿命を延伸するだ けではなく，働くことが可能な期間を延ばす「労働寿命 の延伸」を図っていくことが期待されるようになること を意味する ${ }^{16,17)}$ ，な掞「労働寿命」という言葉は, 調査 した範囲では1956年の高等学校学習指導要領 保健体育 科編の中で確認でき ${ }^{18)}$ ，古くから体力との関係で捉えら れていたことが示唆される。当時と近年とでは平均寿命 も労働形態も大きく異なるため, あたらめて「労働寿命」 について捉え直していくことは意義深い，高齢になって も働きたいと思う人がいきいきと働き続けられるために は，そのための体力，つまり「労働体力」16,17) と言える 身体機能の維持・向上が重要なアセット形成となる，身 体活動・運動にはその面での活用も期待される。単に, 筋力や持久力といった狭義の体力だけでなく, さらに広 い視野から捉えた体力と労働寿命との関係について明ら かにしていくことが，体力科学関係者に突き付けられる 新たな，そして大きな課題と言える。現在，労働遂行 能力に関する指標として, FIOH (Finnish institute of occupational health：フィンランド労衝衛生研究所）が 
開発したWAI (work ability index: 労働適応能力指数) というものが存在する ${ }^{19)}$.このWAIや労働適応能力と 体力や身体活動・運動との関係を示した研究は少なくな いが20-24)，Oakmanらによるシステマティックレビュー /メタアナリシスによると ${ }^{25)}$ ，身体活動・運動による WAIへの介入効果は限定的であり，質の高いさらなる 研究が必要であるとされている.

以上のように労衝衛生・産業保健分野に打けるこれか らの体力科学のあり方として, 身体活動·運動による「リ スク回避要素」に関する研究と「アセット形成要素」に 関する研究，それぞれの進展が今後待ち望まれるが，特 に「アセット形成要素」に関しては研究が進んでいると は言えず, これからの研究の発展が切望される.

\section{身体活動・運動の推進と行動科学的アプローチ}

身体活動・運動の効果を活用する方法に関する研究が 進み，その成果が明らかになったとして，それをもって 労働者の身体活動・運動の推進につながるとは言えない. 身体活動・運動は継続しないと多くの効果は期待できな いが，労働者が実際に身体活動・運動を実践・継続する となると, 行動科学的な視点からのアプローチも重要に なってくる，新 THP指針でも，労働者の積極的な参加 を促すための取組が重視されており，これに関する対策 を検討していくことが求められる，近年では，身体活 動・運動の継続への行動科学的アプローチ法に関する研 究が進んできている.ACSMのガイドラインにおいても, 2014年に発行された第 9 版から,「運動促進に向けた行 動科学的理論と戦略」が 1 つの章を占めるまでに至り ${ }^{26)}$, 第10版ではさらに内容が充実していることから，その価 值への期待が増していることが理解できる27). ACSMの ガイドラインでは, プロチャスカのトランス・セオリティ カルモデルによる行動変容ステージとともに ${ }^{28)}$, 七ルフ エフィカシーの重要性が示されている。これを高める要 素として「達成体験」「代理体験」「言語的説得」「生理 的フィードバック」が紹介されている。 また，この「セ ルフエフィカシーの向上」とは別に「目標設定」「応援・ 励まし」「ソーシャルサポート」「セルフ・モニタリン グ」の重要性も紹介されている. 加えて, 効果的な「目 標設定」の方法としては「SMARTS法則（Specific：明 確かつ具体的であること, Measurable：主観的なもの より数量化されたものであること, Action-oriented：何 が必要であるかを示すこと, Realistic：達成可能であ ること, Timely：時間的枠組みを持たせること, Selfdetermined : 基本的に本人が設定していくこと)」なども 紹介されている27)。これらを職場の実態に即して柔軟に 対応しながら労働者の行動を促す手段として活用してい く工夫が求められる.

\section{産業医科大学における 行動科学的アプローチに関する研究}

筆頭筆者らは, 2014年度から科研費研究として「労働 者に扔ける運動継続への行動変容アプローチに関する研 究」を実施してきた。 その研究結果からは29), 労働者に おいて運動が継続できている人の継続理由（得点化した もの）の上位には,「体力向上」「体型維持」や「健康へ の好影響」など，健康利益に関するものが多いものの, 非継続者に扔いても上位の理由は同様で, 得られる利益 について十分に認識していることがわかった，運動継続 の理由を因子分析したところ,「楽しさ・高揚感」「依存・ 自尊」「外観・陶酔」「健康利益」「飲食的充足」の 5 つの 因子が抽出された。これらのうち「楽しさ・高揚感」の 因子に扔いて, 運動継続者と非継続者との間で顕著な違 いが認められた。この「楽しさ・高揚感」の具体的な要 素が明らかになれば，これを労働者の身体活動・運動の 実施機会にうまくフィードバックすることで，より積極 的な参加を促せる可能性がある。この研究では, 「楽しさ・ 高揚感」の因子を構成する要素として「運動そのものが 楽しい」をはじめ,「運動には予測のできない感動がある」 「自分の居場所がある」「競い合うのが楽しい」「距離や 回数, 記録など達成したい目標がある」「運動でストレ ス発散やリフレッシュができる」「仲間や友人・家族等 といっしょにいるのが楽しい」などが含まれていた。こ れらのうち「自分の居場所がある」「運動でストレス発 散やリフレッシュができる」「仲間や友人・家族等といっ しょにいるのが楽しい」などは，いわゆる「サロン的」 な場や人間関係として位置づけることができ，特に無関 心層が身体活動・運動を始める場合に合うのではないか と考えられる。職場では強制力や義務感のない気軽なク ラブ活動や同好会などが活用できるかもしれない.この 「サロン的」な位置づけに「距離や回数, 記録など達成し たい目標がある」「競い合うのが楽しい」「運動には予測 のできない感動がある」などが加わっていくことで，よ り活動的な楽しさ・高揚感へとつながっていくことが期 待される ${ }^{4)}$.

次に，やや古い資料ではあるが，カイヨワ (Caillois) は「遊びと人間」の中で ${ }^{30)}$, 遊びがもつ「楽しさ」につ いて「アゴン (競争) 」,「アレア (運)」,「ミミクリー (模 倣)」,「イリンクス (眩量)」の 4 つの要素をあげている. これらは多くのスポーツにも含まれる重要な楽しさの要 素であり，我々がスポーツを実施する上で感覚的には把 握している楽しさと言える。これらについて野球を例に 説明すると，得点を競い合ったり (競争), 劣勢での 9 回裏逆転サヨナラ満塁ホームランの可能性（運）に期待 したり，憧れの有名選手の所作を真似たり（模倣），剛 速球投手の投球やホームランバッターの打球といったス 
ピード感に酔いしれたり（眩暈）することに多くの人が 楽しさや高揚感を感じる. 前述の筆頭筆者らの研究では, 運動継続理由としてこれら 4 つの要素に近い項目が含ま れている.「楽しさ・高揚感」の因子の 1 つである「競い 合うのが楽しい」の項目が「競争」の要素, 同じく「楽 しさ・高揚感」の因子の 1 つである「運動には予測ので きない感動がある」の項目が「運」の要素,「依存·自尊」 の因子の 1 つである「好きな人，または尊敬している人 と同じことをしたい」の項目が「模倣」の要素,「外観・ 陶酔」の因子の 1 つである「景色の移ろい，スピード感 やめまいを覚えるのが楽しい」の項目が「眩暈」の要素 と捉えた時, 前者の 2 項目については, 運動継続群と非 継続群との間に有意な得点差が認められており, カイヨ ワの示す「競争」と「運」の 2 つの要素の効果を支持す る可能性がある。一方で, 後者の 2 項目では運動継続者 と非継続者との得点差は認められなかった。このことか ら「模倣」と「眩暈」の要素については支持されない可 能性がある (以上, 文献29内では未考察の結果)。これら については，質問内容が適切だったかどうか等を含めて さらなる検討が必要であるが, 興味深い示唆が得られた。 なお, 海外の研究では, 個人間でもグループ間でも「競争」 を取り入れた集団は運動教室への累積参加数が多かった との報告があり ${ }^{31)}$ ，「競争」を取り入れることの有効性 は十分に期待できる。

他方, 「達成感が味わえる」「運動でストレス発散やリ フレッシュができる」「距離や回数, 記録など達成した い目標がある」の要素も「楽しさ・高揚感」の因子に含 まれている。これらは，前述の ACSMのガイドラインの 中で紹介されているセルフエフィカシーを高める要素と しての「達成体験」や「生理的フィードバック」，また 認知行動的な戦略としての「目標設定」とも整合性がと れており，ガイドラインの推奨内容を支持できるかもし れない，反面で，「言語的説得」とも言える「やらない と叱られる，などの圧力がある(「依存・自尊」の因子 の 1 つ)」の要素は継続理由の得点が最も低く, 運動継 続群と非継続群との差も認められなかったことから,こ れは有効ではない可能性が高い. 依存的になりがちな他 からの圧力は,「言語的説得」だったとしても, 認知行 動的な戦略としての「応援・励まし」とは分けて考える 必要があるかもしれない.

最後に，以上に示した筆頭筆者らの研究結果は，調査 票による横断研究であり因果関係までは明らかになって いないため, こ机に続く研究として，4社の企業・事業 所等で計178名の任意の参加者を対象とした, RCT（randomized controlled trial：無作為化比較試験）による介 入調查を実施している. 現在，この結果を別途論文化し つつあるため詳しい結果は述べられないが，身体活動・ 運動の成果としての「健康利益」を伝えることによる「結
果重視」の支援と, 身体活動・運動や生活そのものを「楽 しむこと」を伝えることによる「過程重視」の支援とでは, 「過程重視群」のほうが「結果重視群」より離脱者が有意 に少なかった ${ }^{322}$. 今後のさらなる分析が必要ではあるが, 「楽しさ・高揚感」の有効性に関する重要な示唆が得ら れた。

\section{産業医科大学における体力科学研究と 健康保持増進への取り組み}

産業医科大学は，「教育基本法及び学校教育法に基づ き，医学及び看護学その他の医療保健技術に関する学問 の教育及び研究を行い，労働環境と健康に関する分野に おけるこれらの学問の振興と人材の育成に寄与するこ と」を目的として，1978年に設立された。端的に言えば 「産業医」「産業保健専門職」を養成する唯一の医科大学 である，基本的に，本学医学部生は卒業後直ちに「産業 医学卒後修練課程」に所属し, 産業医等として勤務する ために必要な専門知識や技能の修練を受ける。前半の 2 年間は臨床研修で医師としての基礎を学び，その後，3 年もしくは 4 年をかけて, 2 つのコース (専門産業医コー ス I：産業医学分野における専門的知識及び技術を有す る産業医等を養成するコース／専門産業医コース II：臨 床医学分野に打ける専門的知識及び技術を有する産業医 等を養成するコース) に分かれて特色ある修練を受ける. この間, 両方のコースで産業医として実際の職務に就く ことが可能である。所定の課程を修了した産業医学修練 医には修了証書が交付される。

この「産業医学卒後修練課程」の中で「健康保持増進」 の理論と実践について講義，実習が実施されている。こ れまでの実習では旧 THP 指針に沿った流れで，その中 心に運動負荷心電図の測定による安全性管理と有酸素能 力の評価, 加えて運動機能測定（いわゆる体力測定）の 実施法とその評価結果をもとにした運動処方の作成に関 する指導が盛り込まれていた。しかし，近年ではで運動 負荷心電図が測定できるような機器・設備等を有してい る企業は稀であり，産業医になってから実用的に行う機 会に乏しいことから，数年前からは運動負荷試験の実践 指導はなくなり，運動機能測定の結果や個人の身体状況 等のみをもとにした指導に関する実習に転換された。こ れを本学の産業生態科学研究所 健康開発科学の教員が 健康管理法全般の講義と共に実施してきた。また筆頭筆 者は2014年まで健康開発科学に所属していたため, その 期間には前者の講義，実習にも関わっていた。

産業医科大学では, この「産業医学卒後修練課程」と は別に, 本学の特徵的研修システムとして, 毎年約 1,000 名の一般医師を対象とする「産業医学基礎研修夏期集 中講座」も開催している。この中でも身体活動・運動に 関して上記と同様の講義・実習を実施している。この集 
中講座におけるへルスプロモーションの話題の中で行動 科学的アプローチ法も含めた講義を, 産業保健学部人 間情報科学の教員の立場で筆頭著者がここ数年担当して きた。これ以外に「産業医学実務講座」や各地の医師会 等が主催する「産業医学生涯研修会」などもあり, これ らに打いても, 「健康保持増進の企画・立案（健康開発 科学)」や「職場に扔ける転倒防止のための体力づくり（人 間情報科学)」「身体活動·運動の継続法 (人間情報科学)」 などの講義・実践も行っている.

体力科学に関する研究については, これまで健康開発 科学を中心に数多くの報告がなされてきており, 過去に は運動による健康効果や運動と酸化ストレスなどに関す

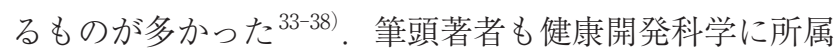
していた期間に, このような課題の研究にも関わってい たが, 人間情報科学へ移動後は, 現在の課題である行動 科学的アプローチ法に関する研究にシフトしてきた。 こ れに関しては前項で述べた通りである。このような研究 成果を上記のような機会を通じて, 労衝衛生・産業保健 関係者へ数多く発信することで，THPに打ける身体活 動·運動の推進に貢献してきた，今後は，新THPの普及· 推進と労働者の身体活動・運動の推進を図っていくとと もに, 労働衛生・産業保健分野における体力科学研究の さらなる発展に寄与していく予定である.

\section{おわりに}

「新 THP指針」では，それぞれの職場における課題や 目標を明確化し，その課題や目標をどのようにして解 決・達成していくのかを具体化することが重要となる. その具体的な方法は多様で決められたものはなく, 独創 性が求められる。したがって, 身体活動・運動の成果を THPに活かしていくためには，選択肢や引き出しをどれ だけ多く持っておくかがポイントとなる。これまでのよ うな, 単にリスク回避的な視点というだけではなく、ア セット形成を目標とする視点や, 身体活動・運動を継続 させていくための行動科学的アプローチの視点などにつ いても考慮していく必要がある。これらに関する研究は 決して十分に進展しているとは言えず, 今後学会をあげ てさらに推進していくことが求められる.

\section{利益相反自己申告：}

本論文に関して著者全員が利益相反はない.

\section{本論文に対する貢献について}

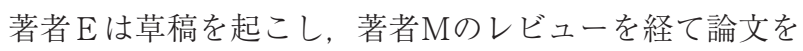
完成させるまで，執筆全体を担当した，著者Mは，新THP 指針㧍よび産業医科大学産業医学卒後修練課程等に関する 情報確認を担当し, 原稿全体を批判的にレビューして論文 の構成㧍よび修正点のチェックを行い, 最終原稿を熟読し た上で投稿を承認した。

\section{文献}

1）内閣府. 平成 28 年度 高齢化の状況及び高齢社会対策の 実施状況, https://www8.cao.go.jp/kourei/whitepaper/ $\mathrm{w}-2017 / \mathrm{html} /$ zenbun/s1_2_4.html（2020年 6 月 23 日 アクセス).

2）経済産業省. 健康経営とは, https://www.meti.go.jp/ policy/mono_info_service/healthcare/kenko_keiei.html (2020年 6 月 23 日 アクセス).

3）厚生労働省. 事業場に扮ける労働者の健康保持増進 のための指針 (改正 令和 2 年 3 月 31 日公示第 7 号). https://www.mhlw.go.jp/content/000616337.pdf (2020 年 6 月 23 日 アクセス).

4）江口泰正 : スポーツと職場の安全・働く人の健康, 安全 衛生コンサルタント, 135: 22-28, 2020.

5) Nutbeam D. The evolving concept of health literacy. Soc Sci Med 67: 2072-2078, 2008. doi: 10.1016/ j.socscimed.2008.09.050.

6）厚生労働省. 平成 30 年版厚生労働白書, https://www. mhlw.go.jp/stf/wp/hakusyo/kousei/18/index.html (2020年 6 月 23 日 アクセス).

7) American College of Sports Medicine. ACSM's guidelines for exercise testing and prescription, tenth edition. Wolters Kluwer, Philadelphia, USA, 1-21, 2018.

8）厚生科学審議会地域保健健康增進栄養部会 次期国民 健康づくり運動プラン策定専門委員会. 健康日本 21 （第二次）の推進に関する参考資料, 厚生労働省, 2012. http://www.mhlw.go.jp/bunya/kenkou/dl/kenkounippon21_02.pdf (2020年 6 月23日 アクセス).

9) Patel AV, Friedenreich CM, Moore SC, Hayes SC, Silver JK, Campbell KL, Winters-Stone K, Gerber LH, George SM, Fulton JE, Denlinger C, Morris GS, Hue T, Schmitz KH, Matthews CE. American College of Sports Medicine Roundtable Report on Physical Activity, Sedentary Behavior, and Cancer Prevention and Control. Med Sci Sports Exerc 51: 2391-2402, 2019. doi: 10.1249/MSS.0000000000002117.

10) Campbell KL, Winters-Stone KM, Wiskemann J, May AM, Schwartz AL, Courneya KS, Zucker DS, Matthews CE, Ligibel JA, Gerber LH, Morris GS, Patel AV, Hue TF, Perna FM, Schmitz KH. Exercise Guidelines for Cancer Survivors: Consensus Statement from International Multidisciplinary Roundtable. Med Sci Sports Exerc 51: 2375-2390, 2019. doi: 10.1249/ MSS.0000000000002116.

11）厚生労働省. 労働災害発生状況, https://www.mhlw. go.jp/bunya/roudoukijun/anzeneisei11/rousai-hassei/ (2020年 6 月 23 日 アクセス).

12) Gillespie LD, Robertson MC, Gillespie WJ, Lamb SE, Gates S, Cumming RG, Rowe BH. Interventions for preventing falls in older people living in the community. Cochrane Database Syst Rev: no. CD007146, 2009. doi: 10.1002/14651858.CD007146.pub2.

13）永田智久. 労働安全衛生システムと健康経営, 職場にお ける身体活動・運動指導の進方, 江口泰正, 中田由夫 編著, 大修館書店, 東京, 25-37, 2018.

14) Nagata T, Mori K, Ohtani M, Nagata M, Kajiki S, Fu- 
jino Y, Matsuda S, Loeppke R. Total Health-Related Costs Due to Absenteeism, Presenteeism, and Medical and Pharmaceutical Expenses in Japanese Employers. J Occup Environ Med 60: e273-e280, 2018. doi: 10.1097/JOM.0000000000001291.

15) Kanamori S, Takamiya $T$, Inoue $S$, Kai $Y$, Kawachi I, Kondo K. Eercising alone versus with others and associations with subjective health status in older Japanese: the JAGES cohort study. Sci Rep 6: art. no.39151, 2016. doi: 10.1038/srep39151.

16）江口泰正：職場における運動・身体活動の推進とへル スプロモーション, 健康開発, 21: 71-80, 2017.

17）江口泰正. 職場におけるへルスプロモーション, 職場に おける身体活動・運動指導の進め方, 江口泰正, 中田由 夫編著, 大修館書店, 東京, 1-11, 2018.

18）文部省. 高等学校学習指導要領 保健体育偏 第 4 章保 健体育科保健, 1956. https://www.nier.go.jp/guideline/ s31hp/chap4.htm（国立教育政策研究所Webサイト： 2020 年 6 月 23 日 アクセス)

19) Tuomi K, Ilmarinen J, Jahkola A, Katajarinne L, Tulkki A. Work Ability Index. Finnish Institute of Occupational Health, 1998.

20) Smolander J, Blair SN, Kohl HW 3rd. Work ability, physical activity, and cardiorespiratory fitness: 2-Year result from project active. J Occup Environ Med 42: 906-910, 2000. doi: 10.1097/00043764-200009000-00012.

21) Sörensen LE, Pekkonen MM, Männikkö KH, Louhevaara VA, Smolander J, Alén MJ. Associations between work ability, health-related quality of life, physical activity and fitness among middle-aged men: Appl. Ergon 39: 786-791, 2008. doi: 10.1016/ j.apergo.2007.11.001.

22) Pohjonen T, Ranta R. Effects of worksite physical exercise intervention on physical fitness, perceived health status, and work ability among home care workers. Five-year follow-up. Prev Med 32: 465-475, 2001. doi: 10.1006/pmed.2001.0837.

23) Ohta M, Eguchi $Y$, Inoue $T$, Honda T, Morita $Y$, Konno Y, Yamato H, Kumashiro M. Effects of bench step exercise intervention on work ability in terms of cardiovascular risk factors and oxidative stress: a randomized controlled study. Int J Occup Saf Ergon 21: 141-149, 2015. doi: 10.1080/10803548.2015.1029293.

24）江口泰正, 太田雅規, 大和 浩, 樋口善之, 泉 博之, 神代雅 晴：労働形態別にみた自覚的ワークアビリティと体力 との関係, 健康開発, 15: 52-58, 2011.

25) Oakman J, Neupane S, Proper KI, Kinsman N, Nygård $\mathrm{CH}$. Workplace interventions to improve work ability: A systematic review and meta-analysis of their effectiveness. Scand J Work Environ Health 44: 134-146, 2018. doi: 10.5271/sjweh.3685.

26) American College of Sports Medicine. ACSM's guide- lines for exercise testing and prescription, Ninth Edition. Wolters Kluwer, Philadelphia, USA, 355-382, 2014.

27) American College of Sports Medicine. ACSM's guidelines for exercise testing and prescription, tenth edition. Wolters Kluwer, Philadelphia, USA, 377-404, 2018.

28) Prochaska JO, Velicer WF. The transtheoretical model of health behavior change. Am J Health Promot 12: 38-48, 1997. doi: 10.4278/0890-1171-12.1.38.

29）江口泰正, 井上彰臣, 太田雅規, 大和 浩：運動継続者 に見られる継続理由の特色, 日本健康教育学会誌, 27 : 256-270, 2019. doi: 10.11260/kenkokyoiku.27.256.

30）Caillois R (多田道太郎, 塚崎幹夫 訳). 遊びと人間, 講談 社, 東京, 42-80, 1973

31) Zhang J, Brackbill D, Yang S, Becker J, Herbert N, Centola D. Support or competition? How online social networks increase physical activity: A randomized controlled trial. Prev Med Rep 4: 453-458, 2016. doi: 10.1016/j.pmedr.2016.08.008.

32）江口泰正, 井上彰臣, 中谷淳子, 黒坂知絵, 山田晋平, 原賀 美紀：労働者の性格特性を考慮した身体活動量向上指 導の介入研究：ランダム化比較試験, 第26回日本行動 医学会学術総会 プログラム・抄録集: p70, 2019.

33) Ikeda M, Matsusaki M, Kinoshita A, Koga M, Ideishi M, Sasaguri M, Tanaka H, Shindo M, Arakawa K. Active and inactive renin after exercise. Eur J Appl Physiol Occup Physiol 65: 331-334, 1992. doi: 10.1007/ BF00868136.

34) Ohta M, Nanri H, Matsushima Y, Sato Y, Ikeda M. Blood pressure-lowering effects of lifestyle modification: possible involvement of nitric oxide bioavailability. Hypertens Res 28: 779-786, 2005. doi: 10.1291/ hypres.28.779.

35) Eguchi M, Ohta M, Yamato $H$. The effect of single long and accumulated short bouts of exercise on cardiovascular risks in male Japanese workers: a randomized controlled study. Ind Health 51: 563-571, 2013. doi: 10.2486/indhealth.2013-0023.

36) Ohta M, Kumashiro M, Eguchi Y, Morita Y, Konno Y, Yamato H. The relationship between work ability and oxidative stress in Japanese workers. Ergonomics 57: 1265-1273, 2014. doi: 10.1080/00140139.2014.914583.

37) Eguchi $Y$, Ohta M, Inoue $T$, Honda T, Morita $Y$, Konno $\mathrm{Y}$, Yamato H. Effects of transitory stimulation interval exercise on physical function: a randomized controlled pilot study among Japanese subjects. J UOEH 34: 297308, 2012. doi: 10.7888/juoeh.34.297.

38) Eguchi Y, Jinde M, Murooka K, Konno Y, Ohta M, Yamato H. Stretching versus transitory icing: which is the more effective treatment for attenuating muscle fatigue after repeated manual labor? Eur J Appl Physiol 114: 2617-2623, 2014. doi: 10.1007/s00421-0142983-x. 